$\xi=$ 离

\title{
Clinical and biochemical aspects associated with diabetic nephropathy among type 2 diabetic males in Gaza strip
}

\author{
Ayman Mustafa Abu Mustafa ${ }^{1 *}$, Maged Mohamed Yassin ${ }^{2}$ \\ ${ }^{1}$ Department of Health Research, Human Resources Development, Ministry of Health, Gaza, Palestine \\ ${ }^{2}$ Department of Physiology, Faculty of Medicine, The Islamic University of Gaza, Palestine \\ *Corresponding author E-mail: myassin@iugaza.edu.ps
}

\begin{abstract}
Background: Diabetic nephropathy (DN) is the leading cause of end-stage renal disease, and the published data on various aspects of the disease is rare in Gaza Strip.

Objective: to investigate clinical and biochemical aspects associated with DN among type 2 diabetic males in Gaza Strip.

Methods: The study comprised 150 type 2 diabetic males from Gaza Strip. Data were obtained from a questionnaire interview, patients' records, and biochemical analysis of blood and urine samples. Statistical analysis was performed using SPSS version 23.

Results: The prevalence of DN was 71/150 (47.3\%). Duration of diabetes in patients with DN was significantly higher than in patients without DN ( $<0.001)$. Smoking, retinopathy, cardiovascular diseases (CVD) and neuropathy were significantly more frequent among patients with DN $(\mathrm{p}<0.05)$. Serum glucose, urea, creatinine, cholesterol and low-density lipoprotein cholesterol (LDL-C) were significantly higher, whereas high-density lipoprotein cholesterol (HDL-C) was significantly lower in patients with DN ( $<<0.05)$. Urinary albumin and Albumin/creatinine ratio (ACR) were 10 to 13 times higher in patients with DN. Conversely, glomerular filtration rate (GFR) was significantly lower in patients with DN $\left(137.1 \pm 35.0\right.$ versus $\left.187.8 \pm 70.8 \mathrm{ml} / \mathrm{min} / 1.73 \mathrm{~m}^{2}, \mathrm{p}<0.001\right)$. ACR showed significant positive correlations with duration of diabetes $(r=0.311, p<0.001)$, glucose $(r=0.308, p<0.001)$, urea $(r=0.474, p<0.001)$, creatinine $(r=0.356$, $\mathrm{p}<0.001)$, cholesterol $(\mathrm{r}=0.307, \mathrm{p}<0.001)$, LDL-C $(\mathrm{r}=0.319, \mathrm{p}<0.001)$ and urinary albumin $(\mathrm{r}=0.942, \mathrm{p}<0.001)$, and significant negative correlation with GFR $(r=-0.297, p<0.001)$. The predicted factors of DN were duration of diabetes, smoking, retinopathy, CVD, neuropathy, glucose, urea, creatinine, cholesterol, LDL-C and GFR. The more to fewer effective predicted variables of ACR were urinary albumin, urea, creatinine, LDL-C, duration of diabetes, glucose, cholesterol and GFR.
\end{abstract}

Conclusion: Management of some predicted factors of DN could delay the progression of the disease.

Keywords: Diabetic Nephropathy; Clinical and Biochemical Aspects; Gaza Strip.

\section{Introduction}

Diabetes mellitus is a group of metabolic diseases characterized by hyperglycemia resulting from defects in insulin secretion, insulin action, or both (American Diabetes Associations, 2014). The main types of diabetes are insulin dependent (type 1) and noninsulin dependent (type 2) diabetes. Type 2 diabetes is much more common than type 1 and usually begins as insulin resistance, a disorder in which the cells do not respond properly to insulin (Ozougwu et al. 2013). Reduce peripheral insulin sensitivity with increased hepatic glucose output resulting in the development of hyperglycemia (König \& Holzhütter 2012). Additionally, high levels of circulating fatty acids due to promotion of lipolysis, elevated levels of triglycerides, cholesterol and LDL-C with low levels of HDL-C were recognized in type 2 diabetic patients (Abd El-Azim et al. 2013; Sabahelkhier et al. 2016).

The chronic hyperglycemia of diabetes is associated with longterm damage, dysfunction, and failure of different organs, especially the eyes, kidneys, nerves, heart, and blood vessels. DN is one of the most severe chronic complications of diabetes and is characterized by an increased urinary albumin excretion in the absence of other renal diseases (Yassin et al. 2011; Bennett and Aditya 2015). Microalbuminuria or incipient nephropathy is the earliest clinical evidence of DN (ACR of $30-300 \mathrm{mg} / \mathrm{g}$, equivalent to timed collections of $30-300 \mathrm{mg} / 24$ hours). Progression to macroalbuminuria or overt nephropathy is heralded by a urinary albumin excretion of $>300 \mathrm{mg} / 24$ hours or ACR $>300 \mathrm{mg} / \mathrm{g}$ and is more likely to be associated with the development of end-stage renal disease (Reutens 2013; Lim 2014).

In addition to albuminuria, GFR was identified as the other diagnostic modality of DN (Tuttle et al. 2014; Kim et al. 2016). The GFR is considered to be the most reliable measure of the functional capacity of the kidneys and is often thought of as indicative of the number of functioning nephrons. It has been proved to be the most sensitive and specific marker of changes in overall renal function (Burtis et al. 2006). A low or decreasing GFR is a good index of chronic kidney disease. Since the total kidney GFR is equal to the sum of the filtration rates in each of the functioning nephrons, the total GFR can be used as an index of functioning renal mass. A decrease in GFR precedes kidney failure in all forms of progressive kidney disease. Monitoring changes in GFR can delineate progression of kidney disease (Krishnaswamy \& Lukose 2015).

Although DN is difficult to capture in the earliest stage because loss of signs and symptoms, its global prevalence is estimated to vary between $5 \%$ and $30 \%$ in patients with type 2 diabetes and microalbuminurea are present in about $40 \%$ of the subjects after 10 years of evolution. The risk of a progressive increase in albumin excretion to overt proteinuria within 6-14 years was $60-80 \%$ 
(Ritz Zeng 2011; Ono et al. 2014; Zenteno-Castillo et al. 2015). In Gaza Strip, thereares no real figures on the prevalence of DN and even researchinton the disease is lacking and restricted to few annual unpublished reports emerged from the Palestinian Ministry of Health. To our best knowledge, the present study is the first to assess clinical and biochemical aspects associated with DN among type 2 diabetic males in Gaza Strip. Understanding such aspects could be useful in the management of the disease.

\section{Methodology}

\subsection{Study design and study population}

The present study was a cross-sectional study. The study population comprised 150 types 2 diabetic males (40-60 years old) who were previously diagnosed according to the current World Health Organization diagnostic criteria for diabetes (World Health Organization, WHO 2006). The patients were selected randomly from the five Diabetic Clinics in the five Governorates of the Gaza Strip, which are the representative clinics for diabetic patients in Gaza Strip, distributed as follows: North 30 (20.0\%), Gaza 50 (33.3\%), Mid-zone 22 (14.7\%), Khan Yunis 30 (20.0\%) and Rafah $18(12.0 \%)$. Patients who have urinary tract infection were excluded.

\subsection{Ethical consideration}

The study was conducted in accordance with the Declaration of Helsinki and was approved by the Local Ethics Research Committee. All subjects provided written informed consent prior to the study.

\subsection{Questionnaire interview}

A meeting interview was used for filling in the questionnaire. All interviews were conducted face to face by one investigator who had a Master degree of Medical Technology. The questionnaire was based on diabetic clinic questions of the Palestinian Ministry of Health with some modifications (Palestinian Ministry of Health 2006). Most questions were the yes/no type, which offer a dichotomous choice (Backestrom \& Hursh-Cesar 2012). A questionnaire was piloted with 10 patients not included in the population sample, and modified as necessary. The questionnaire included questions related to age, smoking, family history of diabetes and diet.

\subsection{Patients' records}

Clinical data including duration of diabetes and diagnosed diabetic complications were obtained from the patients' records.

\subsection{Body mass index}

The body weight and height of each individual dressed in light clothing without shoes were measured using a carefully calibrated balance (Detecto, CAP-180 Kg, USA) for weight and vertical measuring rod for height. The BMI was calculated as $\mathrm{Kg}$ body weight/height in meter squared. People with $\mathrm{BMI}=18.5-24.9$ were considered to have normal weight; people with $\mathrm{BMI}=25.0-29.9$ were classified overweight and people with BMI $\geq 30.0$ were considered obese (WHO 2014).

\subsection{Blood and urine sampling and processing}

Fasting overnight venous blood samples (about $8 \mathrm{ml}$ each) were collected into vacutainer tubes from 150 type 2 diabetic patients by a well-trained medical technologist. The blood samples were left for a while without anticoagulant to allow blood to clot. Then, serum samples were obtained by centrifugation at room temperature using Rotina 46 Hettich Centrifuge, Japan at $4000 \mathrm{rpm} / 10$ minutes to be used for biochemical analysis. Random urine sam- ples were also collected from the patients. The samples were then centrifuged by the same way as serum to precipitate all the debris and then used for urine analysis. For urinary creatinine determination, urine samples were diluted 1/20 (25 urine/475 distilled water).

\subsection{Biochemical analysis}

Serum glucose was measured by glucose oxidase (GOD)/glucose peroxidase (POD) method using Labkit Kits, Spain (Trinder 1969). Serum urea and creatinine were determined by ureaseglutamate dehydrogenase (GDH)/UV method and by Alkaline Picrate method, respectively using BioSystems kit, Spain (Bergmeyer 1974; Fabiny \& Ertingshausen 1971). Serum cholesterol and triglycerides were measured by cholesterol oxidase (COD)/POD method and by glycerol phosphate oxidase/peroxidase method, respectively using BioSystems kit, Spain (Meiatlini et al. 1978; Bucolo \& David 1973). High-density lipoprotein cholesterol (HDL-C) was determined by precipitating method using Labkit kit, Spain (Grove 1979). Low-density lipoprotein cholesterol (LDL-C) was calculated using the empirical relationship of Friedewald (Friedewald et al. 1972).

\subsection{Urine analysis}

Urinary albumin was determined by Immunoturbidometry-Latex method using BioSystems kit, Spain (Harmoinen et al. 1985). Urinary creatinine was measured by kinetic test without deproteinization using DiaSys reagent kits (Bartels et al. 1972). ACR $(\mathrm{mg} / \mathrm{g})=$ microalbumin in urine $(\mathrm{mg} / \mathrm{L}) \times 1000 /$ creatinine in urine $(\mathrm{mg} / \mathrm{dl}) \mathrm{x} 10$. The urine creatinine value was multiplied by 10 in order to convert $\mathrm{mg} / \mathrm{dL}$ into $\mathrm{mg} / \mathrm{L}$, then divide the urine albumin value by the urine creatinine value to arrive at the ratio, then the ratio was multiplied by 1000 to express the value as (mg albu$\mathrm{min} / \mathrm{g}$ creatinine). GFR was calculated by Schwartz equation: GFR $\left(\mathrm{ml} / \mathrm{min} / 1.73 \mathrm{~m}^{2}\right)=0.55 \mathrm{x}$ length $/$ serum creatinine.

\subsection{Data analysis}

Data entry and statistical analyses were performed using Statistical Package for Social Sciences Inc, Chicago, Illinois (SPSS) computer program version 23 for windows. Simple distribution over the study variables and the cross tabulation were applied. Chisquare $\left(\chi^{2}\right)$ was used to identify the significance of the relations between various variables. Means were compared by independentsamples t-test. Pearson's correlation test was applied. Logistic and multiple linear regressions by backward stepwise method were also applied to build model to predict diabetic nephropathy of type 2 diabetes and to predict ACR of studied factors. The results in all the above-mentioned procedures were accepted as statistically significant when the P-value was less than 5\% ( $<<0.05)$. Range as minimum and maximum values was used. The percentage difference was calculated according to the formula: Percentage difference equals the absolute value of the change in value, divided by the average of the 2 numbers, all multiplied by 100 . Percent difference $=(|(\mathrm{V} 1-\mathrm{V} 2)| /((\mathrm{V} 1+\mathrm{V} 2) / 2)) * 100$.

\section{Results}

The mean age of diabetic patients $(n=150)$ was $50.6 \pm 6.2$ years and the mean duration of diabetes was $7.0 \pm 5.8$ years. Diabetic patients since $\leq 5$ years were $76(50.7 \%)$, whereas those with diabetic duration of $6-10$ years were $42(28.0 \%)$. The rest of patients 32 $(21.3 \%)$ had diabetes for more than 10 years. The main diagnosed complications among diabetic patients were retinopathy 36 (24.0\%), cardiovascular diseases $15(10.0 \%)$ and neuropathy 15 (10.0\%). According to ACR, our study population (150 type 2 diabetic patients) were classified into $71(47.3 \%)$ patients with DN (ACR $\geq 30 \mathrm{mg} / \mathrm{g}$ ) and $79(52.7 \%)$ patients without DN (ACR < 30 $\mathrm{mg} / \mathrm{g})$. 


\subsection{General characteristics of diabetic patients with and without DN}

As indicated in Table 1, there were no significant differences between patients with and without DN in terms of age, BMI, family history of diabetes and diet $(p>0.05)$. However, the number of smoker patients with DN 23 (32.4\%) were significantly higher than that of smoker patients without DN $9(11.4 \%)$ with $\chi^{2}=$ 9.828 and $\mathrm{p}=0.002$, indicating that $\mathrm{DN}$ is associated with smoking.

Table 1: General Characteristics of Diabetic Patients with and Without DN

\begin{tabular}{|c|c|c|c|c|c|}
\hline \multirow[b]{2}{*}{ Characteristic } & \multicolumn{2}{|c|}{ Diabetic patients $(n=150)$} & \multirow{2}{*}{\multicolumn{2}{|c|}{ test }} & \multirow[b]{2}{*}{$\mathrm{p}$-value } \\
\hline & $\begin{array}{c}\text { With DN } \\
(\mathrm{n}=71)\end{array}$ & $\begin{array}{c}\text { Without DN } \\
(n=79)\end{array}$ & & & \\
\hline $\begin{array}{l}\text { Age } \pm \text { SD (years) } \\
\text { (Min - max) }\end{array}$ & $\begin{array}{l}51.3 \pm 6.5 \\
(40-60)\end{array}$ & $\begin{array}{c}50.0 \pm 5.9 \\
(40-60)\end{array}$ & $\mathrm{t}$ & 1.246 & 0.215 \\
\hline $\begin{array}{l}\mathrm{BMI} \pm \mathrm{SD}\left(\mathrm{kg} / \mathrm{m}^{2}\right) \\
(\mathrm{Min}-\mathrm{max})\end{array}$ & $\begin{array}{l}30 \pm 4.8 \\
(20-42)\end{array}$ & $\begin{array}{l}30.5 \pm 9.8 \\
(19-109)\end{array}$ & $\mathrm{t}$ & -0.388 & 0.699 \\
\hline \multicolumn{6}{|l|}{ Smoking } \\
\hline $\begin{array}{l}\text { Yes } \\
\text { No }\end{array}$ & $\begin{array}{l}23(32.4) \\
48(67.6)\end{array}$ & $\begin{array}{c}9(11.4) \\
70(88.6)\end{array}$ & $\chi^{2}$ & 9.828 & 0.002 \\
\hline \multicolumn{6}{|l|}{ Family history } \\
\hline $\begin{array}{l}\text { Yes } \\
\text { No }\end{array}$ & $\begin{array}{l}47(66.2) \\
24(33.8)\end{array}$ & $\begin{array}{l}43(54.4) \\
36(45.6)\end{array}$ & $\chi^{2}$ & 2.157 & 0.142 \\
\hline $\begin{array}{l}\text { Diet } \\
\text { Yes } \\
\text { No }\end{array}$ & $\begin{array}{l}29(40.8) \\
42(59.2)\end{array}$ & $\begin{array}{l}36(45.6) \\
43(54.4)\end{array}$ & $\chi^{2}$ & 0.340 & 0.560 \\
\hline $\begin{array}{l}\text { DN: Diabetic N } \\
\text { BMI=18.5-24.9 } \\
\text { BMI=25.0-29.9 } \\
\text { were considered } \\
\text { BMI where values } \\
\text { 0.05: Not significa }\end{array}$ & $\begin{array}{l}\text { opathy. } \\
\text { consider } \\
\text { classified } \\
\text { e (WHO } \\
\text { expresse }\end{array}$ & $\begin{array}{l}\text { I: Body } \\
\text { to have no } \\
\text { erweight an } \\
\text { 4). Values } \\
\text { means } \pm \text { SL }\end{array}$ & & $\begin{array}{l}\text { dex. Pe } \\
\text { ight, pe } \\
\text { with B } \\
\text { 6) exce } \\
\text { 5: Signi }\end{array}$ & $\begin{array}{l}\text { le with } \\
\text { ole with } \\
I \geq 30.0 \\
\text { age and } \\
\text { cant, } p>\end{array}$ \\
\hline
\end{tabular}

\subsection{Duration of diabetes and diabetic complications among diabetic patients with and without DN}

Table 2 revealed that the mean duration of diabetes in patients with DN was significantly higher than that in patients without DN $(10.3 \pm 6.0$ versus $4.0 \pm 3.5$ years, $p<0.001)$. The percentage of retinopathy, CVD and neuropathy in patients with DN was significantly higher than that in patients without DN $(32.4,18.3$ and $15.5 \%$ versus $17.7,2.5$ and $5.1 \%$ with $\mathrm{p}=0.037, \mathrm{p}=0.001$ and $\mathrm{p}=0.034$, respectively), implying that $\mathrm{DN}$ is associated with retinopathy, CVD and neuropathy.

Table 2: Duration of Diabetes and Diabetic Complications among Diabetic Patients with and Without DN

\begin{tabular}{|c|c|c|c|c|c|}
\hline \multirow[b]{2}{*}{ Characteristic } & \multicolumn{2}{|c|}{ Diabetic patients $(n=150)$} & \multirow{2}{*}{\multicolumn{2}{|c|}{ test }} & \multirow[b]{2}{*}{$\begin{array}{c}\mathrm{p}- \\
\text { value }\end{array}$} \\
\hline & $\begin{array}{l}\text { With DN } \\
(\mathrm{n}=71)\end{array}$ & $\begin{array}{c}\text { Without DN } \\
(n=79)\end{array}$ & & & \\
\hline $\begin{array}{l}\text { Duration of dia- } \\
\text { betes } \pm \text { SD (year) } \\
\text { (Min - max) }\end{array}$ & $\begin{array}{l}10.3 \pm 6.0 \\
(1-25)\end{array}$ & $\begin{array}{l}4.0 \pm 3.5 \\
(1-17)\end{array}$ & $\mathrm{t}$ & 7.962 & $<0.001$ \\
\hline Retinopathy & & & & & \\
\hline $\begin{array}{l}\text { Yes } \\
\text { No }\end{array}$ & $\begin{array}{l}23(32.4) \\
48(67.6)\end{array}$ & $\begin{array}{l}14(17.7) \\
65(82.3)\end{array}$ & $\chi^{2}$ & 4.332 & 0.037 \\
\hline CVD & & & & & \\
\hline $\begin{array}{l}\text { Yes } \\
\text { No }\end{array}$ & $\begin{array}{l}13(18.3) \\
58(81.7)\end{array}$ & $\begin{array}{c}2(2.5) \\
77(97.5)\end{array}$ & $\chi^{2}$ & 10.343 & 0.001 \\
\hline Neuropathy & & & & & \\
\hline $\begin{array}{l}\text { Yes } \\
\text { No }\end{array}$ & $\begin{array}{l}11(15.5) \\
60(84.5)\end{array}$ & $\begin{array}{c}4(5.1) \\
75(94.9)\end{array}$ & $\chi^{2}$ & 4.520 & 0.034 \\
\hline
\end{tabular}
(\%) except duration of diabetes where values are expressed as means $\pm \mathrm{SD}$ $\mathrm{p}<0.05$ : Significant

\subsection{Serum glucose, urea, creatinine and lipid profile of diabetic patients with and without $\mathrm{DN}$}

As illustrated in Table 3, serum glucose was significantly increased in patients with DN compared to patients without DN $(238.7 \pm 80.6$ versus $126.1 \pm 35.5 \mathrm{mg} / \mathrm{dl}, \%$ difference $=61.7$ and $\mathrm{p}<0.001)$. Similarly, serum urea, creatinine, cholesterol and LDL-
$\mathrm{C}$ in patients with $\mathrm{DN}(29.0 \pm 7.0,0.73 \pm 0.16,206.9 \pm 41.6$ and $117.3 \pm 40.9) \mathrm{mg} / \mathrm{dl}$, respectively) were significantly higher than that in patients without $\mathrm{DN}(20.3 \pm 7.0,0.56 \pm 0.18,190.6 \pm 34.4$ and $102.3 \pm 31.7 \mathrm{mg} / \mathrm{dl}$, respectively) with \% differences of $35.3,26.4$, 8.2 and 13.7 and p-values of $<0.001,<0.001,0.009$ and 0.012 , respectively. Serum triglycerides were also increased in patients with $\mathrm{DN}$ but without significant change $(\mathrm{p}=0.166)$. Conversely, serum HDL-C was significantly lower in patients with DN than patients without DN $(41.4 \pm 5.3$ versus $44.3 \pm 6.8 \mathrm{mg} / \mathrm{dl})$ with \% difference of 6.8 and $\mathrm{p}=0.004$ ).

\subsection{Urinary albumin, creatinine, $A C R$ and GFR of dia- betic patients with and without $\mathrm{DN}$}

Table 4 provides urinary albumin and creatinine concentrations as well as ACR and GFR of diabetic patients with and without DN. Urinary albumin concentration was several folds higher in patients with DN than patients without DN $(201.7 \pm 204.2$ versus $18.3 \pm 12.7$ $\mathrm{mg} / \mathrm{dl}, \%$ difference $=166.7, \mathrm{p}<0.001)$. However, there was no significant difference in urinary creatinine between patients with and without $\mathrm{DN}(\mathrm{p}=0.254)$. Consequently, ACR was several folds higher in patients with DN than patients without DN $(215.7 \pm 216.7$ versus $16.0 \pm 7.8 \mathrm{mg} / \mathrm{g}, \%$ difference $=172.4, \mathrm{p}<0.001$ ). Conversely, GFR was significantly lower in patients with DN than patients without DN $\left(137.1 \pm 35.0\right.$ versus $187.8 \pm 70.8 \mathrm{ml} / \mathrm{min} / 1.73 \mathrm{~m}^{2}$, \% difference $=31.2, \mathrm{p}<0.001)$.

\subsection{ACR in relation to the studied parameters of both patients with and without $\mathrm{DN}(\mathrm{n}=150)$}

Correlations between ACR and the studied parameters of both patients with and without DN are pointed out in Table 5. Pearson correlation coefficient test showed significant positive correlations of ACR with duration of diabetes $(r=0.311, p<0.001)$, glucose $(r=0.308, p<0.001)$, urea $(r=0.474, p<0.001)$, creatinine $(r=0.356$, $\mathrm{p}<0.001)$, cholesterol $(\mathrm{r}=0.307, \mathrm{p}<0.001)$, LDL-C $\quad(\mathrm{r}=0.319$, $\mathrm{p}<0.001)$ and urinary albumin $(\mathrm{r}=0.942, \mathrm{p}<0.001)$, and significant negative correlation with GFR $(r=-0.297, p<0.001)$ in both patients with and without DN. However, ACR exhibited no significant correlations with age, BMI, triglycerides, HDL-C and urinary creatinine.

\subsection{Logistic regression model for independent variables to predict DN}

As depicted from Table 6, the adjusted odd ratios with $95 \% \mathrm{CI}$ for all independent variables revealed that the predicted factors of DN among type 2 diabetic patients in Gaza Strip were duration of diabetes [OR=1.321, 95\% CI (1.200-1.454), $\mathrm{p}<0.001]$, smoking $[\mathrm{OR}=3.727,95 \%$ CI $(1.587-8.752), \mathrm{p}=0.003]$, retinopathy [OR=2.225, 95\% CI (1.038-4.766), $\mathrm{p}=0.040], \mathrm{CVD}$ [OR=8.629, 95\% CI $(1.874-39.740), \mathrm{p}=0.006]$, neuropathy [OR=3.437, 95\% CI $(1.042-11.341), \mathrm{p}=0.043]$, glucose [OR=1.042, 95\% CI $(1.028$ $1.057), \mathrm{p}<0.001]$, urea $[\mathrm{OR}=1.233,95 \%$ CI $(1.143-1.330)$, $\mathrm{p}<0.001]$, creatinine $[\mathrm{OR}=461.835,95 \%$ CI $(38.731-5507.0)$, $\mathrm{p}<0.001]$, cholesterol $[\mathrm{OR}=1.012, \quad 95 \%$ CI $(1.003-1.021)$, $\mathrm{p}=0.012]$, LDL-C $[\mathrm{OR}=1.012,95 \%$ CI $(1.002-1.021), \mathrm{p}=0.015]$, and GFR [OR $=0.979,95 \% \mathrm{CI}(0.970-0.988), \mathrm{p}<0.001]$.

\subsection{Multiple linear regression model to predict ACR of diabetic patients}

As shown in Table 7, multiple linear regression analysis demonstrated that the predict variables from more to less effective to predict ACR were urinary albumin [ $\mathrm{t}=34.242, \mathrm{p}<0.001]$, urea $[\mathrm{t}=6.551, \mathrm{p}<0.001]$, creatinine $[\mathrm{t}=4.630, \mathrm{p}<0.001] \quad$ LDL-C, $[\mathrm{t}=4.091, \mathrm{p}<0.001]$, duration of diabetes $[\mathrm{t}=3.985, \mathrm{p}<0.001]$, glucose $[\mathrm{t}=3.941, \mathrm{p}<0.001]$, cholesterol $[\mathrm{t}=3.917, \mathrm{p}<0.001]$ and GFR $[\mathrm{t}=-3.784, \mathrm{p}<0.001]$. 
Table 3: Serum Glucose, Urea, Creatinine and Lipid Profile of Diabetic Patients with and Without DN

\begin{tabular}{|c|c|c|c|c|c|}
\hline \multirow[b]{2}{*}{ Variable } & \multicolumn{2}{|c|}{ Diabetic patients $(n=150)$} & \multirow[b]{2}{*}{$\begin{array}{c}\% \\
\text { difference } \\
\end{array}$} & \multirow[b]{2}{*}{ t-test } & \multirow[b]{2}{*}{$\mathrm{p}$-value } \\
\hline & $\begin{array}{c}\text { With DN } \\
(\mathrm{n}=71)\end{array}$ & $\begin{array}{c}\text { Without DN } \\
(n=79)\end{array}$ & & & \\
\hline $\begin{array}{l}\text { Glucose }(\mathrm{mg} / \mathrm{dl}) \\
(\text { Min - max) }\end{array}$ & $\begin{array}{c}238.7 \pm 80.6 \\
(75-460)\end{array}$ & $\begin{array}{c}126.1 \pm 35.5 \\
(72-217)\end{array}$ & 61.7 & 11.270 & $<0.001$ \\
\hline $\begin{array}{l}\text { Urea }(\mathrm{mg} / \mathrm{dl}) \\
(\text { Min }-\max )\end{array}$ & $\begin{array}{c}29.0 \pm 7.0 \\
(12-59)\end{array}$ & $\begin{array}{c}20.3 \pm 7.0 \\
(8-40)\end{array}$ & 35.3 & 7.572 & $<0.001$ \\
\hline $\begin{array}{l}\text { Creatinine }(\mathrm{mg} / \mathrm{dl}) \\
(\text { Min - max })\end{array}$ & $\begin{array}{c}0.73 \pm 0.16 \\
(0.3-1.4)\end{array}$ & $\begin{array}{c}0.56 \pm 0.18 \\
(0.2-1.1)\end{array}$ & 26.4 & 5.948 & $<0.001$ \\
\hline $\begin{array}{l}\text { Cholesterol }(\mathrm{mg} / \mathrm{dl}) \\
(\text { Min - max })\end{array}$ & $\begin{array}{c}206.9 \pm 41.6 \\
(116-315)\end{array}$ & $\begin{array}{c}190.6 \pm 34.4 \\
(88-276)\end{array}$ & 8.2 & 2.636 & 0.009 \\
\hline $\begin{array}{l}\text { Triglycerides }(\mathrm{mg} / \mathrm{dl}) \\
(\text { Min }-\max )\end{array}$ & $\begin{array}{c}243.1 \pm 108.9 \\
(66-759)\end{array}$ & $\begin{array}{c}220.1 \pm 93.2 \\
(79-650)\end{array}$ & 9.9 & 1.393 & 0.166 \\
\hline $\begin{array}{l}\mathrm{HDL}-\mathrm{C}(\mathrm{mg} / \mathrm{dl}) \\
(\mathrm{Min}-\mathrm{max})\end{array}$ & $\begin{array}{c}41.4 \pm 5.3 \\
(28-54)\end{array}$ & $\begin{array}{c}44.3 \pm 6.8 \\
(31-89)\end{array}$ & -6.8 & -2.937 & 0.004 \\
\hline $\begin{array}{l}\text { LDL-C (mg/dl) } \\
(\mathrm{Min}-\max )\end{array}$ & $\begin{array}{c}117.3 \pm 40.9 \\
(27-222)\end{array}$ & $\begin{array}{c}102.3 \pm 31.7 \\
(29-185)\end{array}$ & 13.7 & 2.541 & 0.012 \\
\hline
\end{tabular}

DN: Diabetic Nephropathy. HDL-C: High density lipoprotein cholesterol, LDL-C: Low density lipoprotein cholesterol. All values are expressed as mean \pm SD. $\mathrm{p}<0.05$ : Significant, $\mathrm{p}>0.05$ : Not significant.

Table 4: Urinary Albumin, Creatinine, ACR and GFR of Diabetic Patients with and Without DN

\begin{tabular}{|c|c|c|c|c|c|}
\hline \multirow[b]{2}{*}{ Variable } & \multicolumn{2}{|c|}{ Diabetic patients $(n=150)$} & \multirow{2}{*}{$\begin{array}{c}\% \\
\text { difference }\end{array}$} & \multirow[b]{2}{*}{ t-test } & \multirow[b]{2}{*}{$\mathrm{p}$-value } \\
\hline & $\begin{array}{c}\text { With DN } \\
(\mathrm{n}=71)\end{array}$ & $\begin{array}{c}\text { Without DN } \\
(n=79)\end{array}$ & & & \\
\hline $\begin{array}{l}\text { Urinary Albumin (mg/dl) } \\
\text { (Min - max) }\end{array}$ & $\begin{array}{c}201.7 \pm 204.2 \\
(18-1063)\end{array}$ & $\begin{array}{c}18.3 \pm 12.7 \\
(3-79)\end{array}$ & 166.7 & 7.970 & $<0.001$ \\
\hline $\begin{array}{l}\text { Urinary creatinine }(\mathrm{mg} / \mathrm{dl}) \\
(\text { Min - max) }\end{array}$ & $\begin{array}{c}99.0 \pm 50.3 \\
(28-347)\end{array}$ & $\begin{array}{c}107.3 \pm 38.2 \\
(22-232)\end{array}$ & -8.0 & -1.144 & 0.254 \\
\hline $\begin{array}{l}\text { ACR }(\mathrm{mg} / \mathrm{g}) \\
(\text { Min - max) }\end{array}$ & $\begin{array}{c}215.7 \pm 216.7 \\
(31-1328)\end{array}$ & $\begin{array}{l}16.0 \pm 7.8 \\
(1.9-29)\end{array}$ & 172.4 & 7.761 & $<0.001$ \\
\hline
\end{tabular}

DN: Diabetic Nephropathy. ACR: Albumin/creatinine ratio, GFR: Glomerular filtration rate. All values are expressed as mean \pm SD. $\mathrm{p}<0.05$ : Significant, $\mathrm{p}>0.05$ : Not significant.

Table 5: ACR In Relation To the Studied Parameters of Both Patients with and Without DN

\begin{tabular}{|c|c|c|}
\hline \multirow[t]{2}{*}{ Parameter } & \multicolumn{2}{|c|}{$\begin{array}{c}\mathrm{ACR}(\mathrm{mg} / \mathrm{g}) \\
(\mathrm{n}=150)\end{array}$} \\
\hline & $\mathrm{r}$ & p-value \\
\hline Age (years) & 0.034 & 0.676 \\
\hline Duration of diabetes (Year) & 0.311 & $<0.001$ \\
\hline BMI $\left(\mathrm{kg} / \mathrm{m}^{2}\right)$ & -0.029 & 0.727 \\
\hline Glucose (mg/dl) & 0.308 & $<0.001$ \\
\hline Urea (mg/dl) & 0.474 & $<0.001$ \\
\hline Creatinine (mg/dl) & 0.356 & $<0.001$ \\
\hline Cholesterol (mg/dl) & 0.307 & $<0.001$ \\
\hline Triglycerides (mg/dl) & 0.049 & 0.552 \\
\hline HDL-C (mg/dl) & -0.153 & 0.061 \\
\hline LDL-C (mg/dl) & 0.319 & $<0.001$ \\
\hline Urinary Albumin (mg/dl) & 0.942 & $<0.001$ \\
\hline Urinary creatinine $(\mathrm{mg} / \mathrm{dl})$ & -0.085 & 0.304 \\
\hline $\operatorname{GFR}\left(\mathrm{ml} / \mathrm{min} / 1.73 \mathrm{~m}^{2}\right)$ & -0.297 & $<0.001$ \\
\hline
\end{tabular}

Table 6: Logistic Regression Model for Independent Variables to Predict DN

\begin{tabular}{|c|c|c|c|c|c|c|c|}
\hline \multirow{2}{*}{ Factor } & \multirow{2}{*}{ B } & \multirow{2}{*}{ S.E. } & \multirow{2}{*}{ Wald } & \multirow{2}{*}{ p-value } & \multirow{2}{*}{ Odds* } & \multicolumn{2}{|c|}{$95 \%$ CI for OR } \\
\hline & & & & & & Lower & Upper \\
\hline Duration of diabetes (Year) & 0.278 & 0.049 & 32.402 & $<0.001$ & 1.321 & 1.200 & 1.454 \\
\hline Smoking & 1.316 & 0.436 & 9.123 & 0.003 & 3.727 & 1.587 & 8.752 \\
\hline CVD & 2.155 & 0.779 & 7.650 & 0.006 & 8.629 & 1.874 & 39.740 \\
\hline Neuropathy & 1.235 & 0.609 & 4.110 & 0.043 & 3.437 & 1.042 & 11.341 \\
\hline Glucose (mg/dl) & 0.042 & 0.007 & 35.496 & $<0.001$ & 1.042 & 1.028 & 1.057 \\
\hline Urea (mg/dl) & 0.209 & 0.039 & 29.279 & $<0.001$ & 1.233 & 1.143 & 1.330 \\
\hline Cholesterol (mg/dl) & 0.012 & 0.005 & 6.381 & 0.012 & 1.012 & 1.003 & 1.021 \\
\hline LDL-C (mg/dl) & 0.012 & 0.005 & 5.952 & 0.015 & 1.012 & 1.002 & 1.021 \\
\hline $\operatorname{GFR}\left(\mathrm{ml} / \mathrm{min} / 1.73 \mathrm{~m}^{2}\right)$ & -0.021 & 0.005 & 19.541 & $<0.001$ & 0.979 & 0.970 & 0.988 \\
\hline
\end{tabular}

*Adjusted Odd Ratio, CVD: Cardiovascular disease, LDL-C: Low density lipoprotein cholesterol, GFR: Glomerular filtration rate. p < 0.05: Significant. 
Table 7: Multiple Linear Regression Model to Predict ACR (Mg/G) Of Diabetic Patients

\begin{tabular}{|c|c|c|c|c|c|c|}
\hline \multirow{2}{*}{ Predictors } & \multirow{2}{*}{ B } & \multirow{2}{*}{ SE } & \multirow{2}{*}{$\mathrm{t}$} & \multirow{2}{*}{ p-value } & \multicolumn{2}{|c|}{$95 \% \mathrm{CI}$ for $\mathrm{B}$} \\
\hline & & & & & Lower & Upper \\
\hline Urinary Albumin (mg/dl) & 1.007 & 0.029 & 34.242 & $<0.001$ & 0.949 & 1.065 \\
\hline Urea $(\mathrm{mg} / \mathrm{dl})$ & 10.289 & 1.571 & 6.551 & $<0.001$ & 7.185 & 13.393 \\
\hline LDL-C (mg/dl) & 1.544 & 0.377 & 4.091 & $<0.001$ & 0.798 & 2.290 \\
\hline Duration of diabetes (Year) & 9.665 & 2.425 & 3.985 & $<0.001$ & 4.873 & 14.458 \\
\hline Glucose (mg/dl) & 0.665 & 0.169 & 3.941 & $<0.001$ & 0.332 & 0.999 \\
\hline Cholesterol (mg/dl) & 1.417 & 0.362 & 3.917 & $<0.001$ & 0.702 & 2.131 \\
\hline
\end{tabular}

ACR: Albumin/creatinine ratio, LDL-C: low density lipoprotein cholesterol, GFR: Glomerular filtration rate. B: regression coefficient, SE: standard errors. $\mathrm{p}<0.05$ : Significant.

\section{Discussion}

Type 2 diabetes mellitus is being increased in Gaza strip, particularly in the last decade. However, no real figures are available on its prevalence and its complications. In fact, there is a scarcity of data on the development of the disease towards DN evident by micro- and/or macroalbuminurea. Only one published study related diabetes with DN in type 2 diabetic patients in Gaza strip (Yassin et al. 2011). Recently, another study has recognized diabetes mellitus as one of the most common risk factor associated with end-stage renal disease in Gaza Strip (Abu-Odah et al. 2016). This necessitates further research on various features of DN. Therefore, the present study is the first to assess the frequency of DN among a population sample of type 2 diabetic males in Gaza Strip as well as to investigate clinical and biochemical aspects associated with DN not only in blood but also in urine to get a clear and broad picture on patient condition, and to help in the disease management.

The mean age within the study population (type 2 diabetic patients) was $50.6 \pm 6.2$ years, which coincides with the fact that type 2 diabetes mellitus usually develops at older age (Bhalerao et al. 2014). The finding that almost half of the study population had diabetes for 5 years or less does confirm the idea that type 2 diabetes has a long asymptomatic pre-clinical phase which frequently goes undetected. At the time of diagnosis, the patient could have one or more diabetes complications (Shaikh et al. 2008; Yassin et al. 2011). Indeed, retinopathy, CVD and neuropathy were the main diagnosed complications among our diabetic patients. We then moved one step ahead depending on ACR and classified diabetic patients into patients with $\mathrm{DN}(\mathrm{ACR} \geq 30 \mathrm{mg} / \mathrm{g}$ ) and patients without DN (ACR $<30 \mathrm{mg} / \mathrm{g}$ ). This enable us to assess various aspects of DN in type 2 diabetic patients.

The prevalence of DN among our population sample of 150 type 2 diabetic patients was $47.3 \%$. There was no previous study assessed the prevalence of DN in Gaza Strip neither at a small nor at a large diabetic population scale. Nevertheless, our figure of DN prevalence coincides with that previously reported (Prakash et al. 2006; Ono et al. 2014). Further research is required on a large sample size at a national level. There were no significant differences between patients with and without DN in terms of age, BMI, family history of diabetes and diet. However, DN was associated with smoking. It is accepted that smoking promotes diabetic microalbuminuria and exacerbates DN (Jose et al. 2016).

The present data pointed out that the mean duration of diabetes in patients with DN was significantly higher than that in patients without DN i.e. the longer the duration of diabetes, the more the progression of DN. Similar results were documented (Viswanathan et al. 2012; Radcliffe et al. 2017). In addition, diagnosed complications, including retinopathy, CVD and neuropathy were significantly more frequent in patients with $\mathrm{DN}$ than in patients without DN. This means that DN is associated with higher rate of retinopathy, cardiovascular diseases and neuropathy. Such findings are in accordance with that reported by other authors (Pálsson \& Patel 2014; Bennett \& Aditya 2015; Rodríguez-Poncelas et al. 2016). In this context, the development of such complications particularly CVD would be accelerated and exacerbated in smoker patients with DN.

Serum glucose, urea, creatinine, cholesterol and LDL-C were significantly higher in patients with $\mathrm{DN}$ compared to patients without DN. Conversely, serum HDL-C was significantly lower in patients with DN. Such findings are in agreement with that reported in the literature (Kumawat et al. 2016; Vinoth et al. 2016). The higher levels of serum urea and creatinine in the presence of hyperglycemia in patients with DN indicate progressive renal damage and kidney dysfunction (Bamanikar et al. 2016). Dyslipidemia observed in the present study is also reported to be associated with decreased kidney function in patients with chronic kidney disease (Kawanami et al. 2016). It is worth mentioning that DN plays a critical role as a risk factor for CVD and altered lipid levels will increase the risk. The higher rate of diagnosed CVD among our DN patients does support this view. Therefore, baseline lipid profile during screening programmes for diabetes and monitoring their levels is beneficial.

Urinary albumin concentration and consequently, ACR was several folds higher in patients with DN than patients without DN. Conversely, GFR was significantly lower in patients with DN. Elevation of urinary albumin concentration and hence ACR as well as decrease GFR in DN patients were documented by other authors and explained mostly as a result of impairment of kidney filtration efficiency (Jerums et al. 2009; Lee \& Lam 2015). Thus, we can say that both albuminuria and GFR are integrating biomarkers in screening, diagnosis and monitoring of DN. This is very important as these tests are relatively cheaper and therefore, more affordable compared with other diagnostic tests such as magnetic resonance imaging, computerized tomography scan, which are more expensive and may not be readily affordable by the majority of people in poor areas such as Gaza Strip.

As depicted from Pearson's correlation test, ACR showed significant positive correlations with duration of diabetes, glucose, urea, creatinine, cholesterol, LDL-C and urinary albumin, and significant negative correlation with GFR in both patients with and without DN. Similar findings were reported for other studies (Adewolu \& Atoe 2015; Vinoth et al. 2016; Abbas et al. 2017). Such associations could be used as indicators for the progression of diabetes to DN and even to end-stage renal disease. In this context, logistic regression model revealed that the predicted factors of DN were duration of diabetes, smoking, retinopathy, CVD, neuropathy, glucose, urea, creatinine, cholesterol, LDL-C and GFR. Most of these factors were identified as clinical and biochemical predictive factors in diabetic kidney disease progression (Grover et al. 2012; Radcliffe et al. 2017). However, the exact stage of DN is beyond the scope of this study. In addition, Multiple linear regression model demonstrated that the predict variables from more to less effective to predict ACR was urinary albumin, urea, creatinine, LDL-C, duration of diabetes, glucose, cholesterol and GFR.

In conclusion, the prevalence of DN among diabetic patients in Gaza Strip seems to be alarming. The predicted factors of DN were duration of diabetes, smoking, retinopathy, CVD, neuropathy, glucose, urea, creatinine, cholesterol, LDL-C and GFR. Management of some of these factors could delay the progression of DN. 


\section{References}

[1] Abbas AW, Yousif WH \& Khaleel KJ (2017). Oxidant, antioxidants and some biochemical parameters in patients with type 2 diabetic nephropathy. World Journal of Pharmaceutical Research 6(1), 11-21. https://doi.10.20959/wjpr20171-7494.

[2] Abd El-Azim SA, Hassan SF, El Deib KM \& Barakat MMA (2013). Protective effect of dietary Ginger extract alone or in combination with Rosiglitazone and Glimepiride on hepatotoxicity and oxidative stress in streptozotocin-induced diabetes in rats. International Journal of Advanced Research 1(10), 256-271.

[3] Abu-Odah H, Abed Y, El-Khateeb A, Salah M \& El-Nems K (2016). End-stage renal disease in the Gaza Strip and its relationship to risk factors. Journal of US-China Medical Science 13, 24-34. https://doi.org/10.4172/2161-0959.1000248.

[4] Adewolu OF \& Atoe K (2015). Association between albumin creatinine ratio and e-GFR in type 2 diabetes mellitus patients in Oredo Local Government Area, Benin City, South-South Nigeria. International Journal of Tropical Disease \& Health 6(3), 94-101. https://doi.org/10.9734/IJTDH/2015/14282.

[5] American Diabetes Association (2014). Diagnosis and classification of diabetes mellitus. Diabetes Care 37 (Supplement 1), S81-S90. https://doi.org/10.2337/dc14-S081.

[6] Backestrom C \& Hursh-Cesar G (2012). Survey Research, Pennsylvania, United States: Literary Licensing, LLC, 2012.

[7] Bamanikar SA, Bamanikar AA \& Arora A (2016). Study of serum urea and creatinine in diabetic and non-diabetic patients in a tertiary teaching hospital. The Journal of Medical Research 2(1), 12-15.

[8] Bartels H, Bohmer M \& Heierli G (1972). Serum creatinine determination without protein precipitation. Clinica Chimica Acta 37, 193-197. https://doi.org/10.1016/0009-8981(72)90432-9.

[9] Bennett K \& Aditya BS (2015). An overview of diabetic nephropathy: Epidemiology, pathophysiology and treatment. Journal of Diabetes Nursing 19(2), 61-67.

[10] Bergmeyer HU (1974). Methods of enzymatic analysis, 2nd edition, Weinheim, Verlag Chemie, New York, Academic Press.

[11] Bhalerao SD, Somannavar M, Vernekar SS, Ravishankar R \& Goudar SS (2014). Risk factors for type 2 diabetes mellitus in rural population of north karnataka: a community-based cross-sectional study. International Journal of Pharma Medicine and Biological Sciences 3(1), 1-14

[12] Bucolo G \& David H (1973). Quantitative determination of serum triglycerides by use of enzymes. Clinical Chemistry 19, 476-482.

[13] Burtis CA, Ashwood ER \& Bruns DE (2006). Tietz Textbook of Clinical Chemistry and Molecular Diagnostics, 4th edition, USA, Elsevier.

[14] Fabiny DL \& Ertingshausen G (1971). Automated reaction-rate method for determination of serum creatinine with the CentrifiChem. Clinical Chemistry 17, 696-700.

[15] Friedewald WT, Levy RI \& Fredrickson DS (1972). Estimation of the concentration of LDL-C in plasma without use of the preparative ultracentrifuge. Clinical Chemistry 18, 499-502.

[16] Grove TH (1979). Effect of reagent $\mathrm{pH}$ on determination of HDL cholesterol by precipitation with sodium phosphotungstatemagnesium. Clinical Chemistry 25, 560-564.

[17] Grover G, Gadpayle AK \& Sabharwal A (2012). Identifying patients with diabetic nephropathy based on serum creatinine in the presence of covariates in type-2 diabetes: A retrospective study. $\mathrm{Bi}$ omed Research India 23(4), 615-624.

[18] Harmoinen A, Ala-Houhala I \& Vuorinen P (1985). Rapid and sensitive immunoassay for albumin determination in urine. Clinica Chimica Acta 149(2-3), 269-274. https://doi.org/10.1016/00098981(85)90341-9.

[19] Jerums G, Panagiotopoulos S, Premaratne E, MacIsaac RJ (2009). Integrating albuminuria and GFR in the assessment of diabetic nephropathy. Nature Reviews Nephrology 5(7), 397-406. https://doi.org/10.1038/nrneph.2009.91.

[20] Jose MJ, Varkey V, Chandni R, Zubaida PA \& Maliekkal J (2016) The role of smoking as a modifiable risk factor in diabetic nephropathy. The Journal of the Association of Physicians of India 64, 34 38.

[21] Kawanami D, Matoba K \& Utsunomiya K (2016). Dyslipidemia in diabetic nephropathy. Renal Replacement Therapy 2, 16.

[22] Kim SS, Kim JH \& Kim IJ (2016). Current challenges in diabetic nephropathy: Early diagnosis and ways to improve outcomes. Endocrinology and Metabolism (Seoul) 31(2), 245-253. https://doi.org/10.3803/EnM.2016.31.2.245.

[23] König M \& Holzhütter HG (2012). Kinetic modeling of human hepatic glucose metabolism in type 2 diabetes mellitus predicts higher risk of hypoglycemic events in rigorous insulin therapy. The Journal of Biological Chemistry 287(44), 36978-36989. https://doi.org/10.1074/jbc.M112.382069.

[24] Krishnaswamy R \& Lukose S (2015). Evaluation of the three methods available for the estimation of creatinine clearance. International Journal of Clinical Biochemistry and Research 2(2), 83-88.

[25] Kumawat M, Dahiya K \& Ghalaut VS (2016). Biochemical markers for the progression of diabetic nephropathy. International Journal of Advanced Research 4(3), 226-230.

[26] Lee C \& Lam KSL (2015). Biomarkers of progression in diabetic nephropathy: The past, present and future. Journal of Diabetes Investigation 6(3), 247-249. https://doi.org/10.1111/jdi.12329.

[27] Lim AKH (2014). Diabetic nephropathy - complications and treatment. International Journal of Nephrology and Renovascular Disease 7, 361-381. https://doi.org/10.2147/IJNRD.S40172.

[28] Meiatlini F, Prencipe L, Bardelli F, Giannini G \& Tarli P (1978) The 4-hydroxybenzoate/4 aminophenazone chromogenic system used in the enzymic determination of serum cholesterol. Clinical Chemistry 24, 2161-2165.

[29] Ono T, Shikata K, Obika M, Miyatake N, Kodera R, Hirota D, Wada J, Kataoka H, Ogawa D \& Makino H (2014). Factors associated with remission and/or regression of microalbuminuria in type $2 \mathrm{di}$ abetes mellitus. Acta Medica Okayama 68(4), 235-241.

[30] Ozougwu JC, Obimba KC, Belonwu CD \& Unakalamba CB (2013) The pathogenesis and pathophysiology of type 1 and type 2 diabetes mellitus. Journal of Physiology and Pathophysiology 4(4), 46-57. https://doi.org/10.5897/JPAP2013.0001.

[31] Palestinian Ministry of Health. Diabetic questionnaire, Diabetic clinic records, Gaza strip, Palestine, 2006.

[32] Pálsson R \& Patel UD (2014). Cardiovascular complications of diabetic kidney disease. Advances in Chronic Kidney Disease 21(3), 273-280. https://doi.org/10.1053/j.ackd.2014.03.003.

[33] Prakash J, Hota JK, Singh S \& Sharma OP (2006). Clinical spectrum of chronic renal failure in the elderly: a hospital based study from eastern India. International Urology and Nephrology 38(3-4), 821-827.

[34] Radcliffe NJ, Seah J, Clarke M, Maclsaac RJ, Jerums G \& Ekinci EI (2017). Clinical predictive factors in diabetic kidney disease progression. Journal of Diabetes Investigation 8(1), 6-18. https://doi.org/10.1111/jdi.12533.

[35] Reutens AT (2013). Epidemiology of diabetic kidney disease. The Medical Clinics of North America 97(1): 1-18.

[36] Ritz E \& Zeng X (2011). Diabetic nephropathy - Epidemiology in Asia and the current state of treatment. Indian Journal of Nephrology 21(2), 75-84. https://doi.org/10.4103/0971-4065.82122.

[37] Rodríguez-Poncelas A, Mundet-Tudurí X, Miravet-Jiménez S, Casellas A, Barrot-De la Puente JF, Franch-Nadal J \& Coll-de Tuero G (2016). Chronic kidney disease and diabetic retinopathy in patients with type 2 diabetes. PLoS One 11(2), e0149448.

[38] Sabahelkhier MK, Awadllah MA, Idrees ASM, Mohammed AAA \& Idris MA (2016). A Study of lipid profile levels of type II diabetes mellitus. Nova Journal of Medical and Biological Sciences 5(2), 1-9. https://doi.org/10.20286/nova-jmbs-050203.

[39] Shaikh MA, Yakta D, Baloch GH \& Shaikh D (2008). The age of onset of type 2 diabetes mellitus in adult population. Annals of $\mathrm{Pa}$ kistan Institute of Medical Sciences 4(2), 109-112.

[40] Trinder P (1969). Determination of glucose in blood using glucose oxidase. Annals of Clinical Biochemistry 6, 24-33. https://doi.org/10.1177/000456326900600108.

[41] Tuttle KR, Bakris GL, Bilous RW, Chiang JL, de Boer IH, Goldstein-Fuchs J, Hirsch JB, Kalantar-Zadeh K, Narva AS, Navaneethan SD, Neumiller JJ, Patel UD, Ratner RE, Whaley-Connell AT \& Molitch ME (2014). Diabetic kidney disease: a report from an ADA Consensus Conference. Diabetes Care 37(10), 2864-2883. https://doi.org/10.2337/dc14-1296.

[42] Vinoth M, Pinto NR, Ferreira A, Vaz F \& Perni S (2016). Lipid profile of diabetic kidney disease patients in rural goa, india. Journal of Medical and Dental Science Research 3(4), 25-28.

[43] Viswanathan V, Tilak P \& Kumpatla S (2012). Risk factors associated with the development of overt nephropathy in type 2 diabetes patients: A 12 years observational study. The Indian Journal of Medical Research 136(1), 46-53.

[44] World Health Organization. Definition and diagnosis of diabetes mellitus and intermediate hyperglycemia Report of a WHO/IDF Consultation. Geneva, WHO, 2006.

[45] World Health Organization. Ten facts on obesity, 2014. Available at: http://www.who.int/features/factfiles/obesity/en/ (accessed 13 April, 2017)

[46] Yassin MM, Altibi HI \& El Shanti AF (2011). Clinical and biochemical features of type 2 diabetic patients in Gaza Governorate, 
Gaza Strip. West African Journal of Medicine 30(1), 51-56. https://doi.org/10.4314/wajm.v30i1.69918.

[47] Zenteno-Castillo P, Muñoz-López DB, Merino-Reyes B, VegaSánchez A, Preciado-Puga M, González-Yebra AL \& Kornhauser C (2015). Prevalence of diabetic nephropathy in type 2 diabetes mellitus in rural communities of Guanajuato, Mexico. Effect after 6 months of Telmisartan treatment. Journal of Clinical \& Transla- 